\title{
ПРАВОВЕ РЕГУЛЮВАННЯ ПОВОДЖЕННЯ 3 БЕЗПРИТУЛЬНИМИ ТВАРИНАМИ В УКРАЇНІ
}

\author{
Чурилова Т. М., Стрельник В. В.
}

\section{ВСТУП}

За останні 15 тис. років процес доместикації був застосований до великої кількості диких тварин. Першим супутником людини став вовк, селекційним підвидом якого $є$ собака. Процес зміни популяції котів відбувся на 5 тис. років пізніше. Собаки допомагали людям у мисливстві й охороні помешкання, а коти - в боротьбі із гризунами. Тварин почали утримувати для спілкування, отримання додаткових позитивних емоцій, вони ставали повноправними членами сімей. Під впливом людини змінювались їхня поведінка, зовнішній вигляд. У науковій літературі набір ознак, що відрізняє їх від диких тварин, називається синдромом одомашнення. Внаслідок таких змін собаки та коти більше не могли вижити без людини, а люди стали відповідальними за їхню долю ${ }^{1}$.

У подальшому безвідповідальність (відмова власників від утримання тварин, не розрахований час, який необхідний для догляду), відсутність фінансових можливостей на утримання, проблеми із житлом спричинили появу на вулицях населених пунктів великої кількості безпритульних тварин, особливо котів і собак, що сприяло зростанню їх популяції спадково.

До того ж відсутність дієвого законодавства, здатного забезпечувати належне життя вихованців, зумовлює актуальність проблеми поводження з безпритульними тваринами в Україні.

Питання поводження із безпритульними тваринами залишається невирішеним практично для всіх країн світу. Гуманність підходів вирішення такого питання залежить від різних аспектів, у тому числі від рівня економічного розвитку країни. Махатма Ганді казав, що про моральний розвиток нації свідчать методи поводження суспільства 3 тваринами. Ставлення до тварин є маркером цивілізованості суспільства. Від усвідомлення своєї природи, місця у світі залежить подальша доля не тільки тварин, а й самої людини. Погоджуємося 3 думкою О.Є. Гомілко, що «усвідомлення вітальної спорідненості людини та тварини сприяє виробленню глибинно екологічного (deep

\footnotetext{
1 Mice Change Their Appearance as a Result of Frequent Exposure to Humans. URL: https://www.technology.org/2018/03/16/mice-change-their-appearance-as-a-result-of-frequentexposure-to-humans/ (дата звернення 16.02.2020).
} 
ecology) мислення, котре визнає цінність за кожною живою істотою, незважаючи на її утилітарну (корисну для потреб людей) значущість. Актуальність такого мислення визначено не лише сферою моралі, але й потребами вдосконалення соціуму. Права людини як стрижневий концепт сучасного цивілізованого людства мають бути доповнені визнанням права на життя та відсутність страждань тварин»².

Україна, яка обрала європейський вектор розвитку, не змінила жорстокі радянські підходи в поводженні з безпритульними тваринами. Так, замість стерилізації тварин піддають евтаназії. Практично не застосовуються заходи (за виключенням окремих населених пунктів, зокрема Львів), які б попереджали збільшення їх кількості. Ситуація ускладнюється низьким рівнем соціальної емпатії й обізнаності громадськості, не вживаються заходи для підвищення свідомості населення, зокрема власників тварин. Через це кількість безпритульних тварин продовжує зростати ${ }^{3}$.

Переконані, що вирішення означених проблем стане можливим лише за умови комплексного підходу, системної роботи як на державному, так і на локальних рівнях. Стандарти гуманного поводження 3 тваринами є однією з європейських цінностей, сприйняття та втілення яких є необхідними з огляду на євроінтеграційні процеси в Україні.

Пошук дієвого й адаптованого до реалій сьогодення правового регулювання поводження з безпритульними тваринами в Україні є метою цього дослідження. Побудова ефективної системи регуляції чисельності популяції безпритульних тварин гуманними методами неможлива без аналізу міжнародних стандартів, світового досвіду у сфері захисту домашніх тварин.

\section{1. Міжнародно-правове регулювання прав тварин}

У XX ст. було прийнято низку міжнародних декларацій у сфері прав тварин. Важливою подією стало оголошення Всесвітньої Декларації прав тварин (Universal Declaration of Animal Rights), що була прийнята Міжнародною Лігою Прав тварин 23 вересня 1977 р. у Лондоні. Декларація визнає, що всі живі істоти мають свої природні права, будь-яка тварина 3 нервовою системою наділяється особливими правами. Неповага, ігнорування природних прав завдають великої шкоди

2 Гомілко О. Вітальна єдність людини та тварини: свідомість як квалія. URL: http://ekmair.ukma.edu.ua/handle/123456789/13358

3 Безпритульні тварини: вбити неможливо прихистити? Екологія. Право. Людина. URL: http://epl.org.ua/eco-analytics/bezprytulni-tvaryny-vbyty-nemozhlyvo-pryhystyty/ (дата звернення: 17.02.2020). 
природі, спричиняють скоєння злочинів проти тварин. Повага до тварин $є$ невід'ємною складовою частиною від поваги людини до людини ${ }^{4}$.

Відповідно до ст. 5 Декларації будь-яка тварина, що знаходиться в залежності від людини, має право на належні догляд і турботу, не може бути кинута напризволяще або невиправдано вбита. Виставки, демонстрації та фільми, до яких залучають тварини, мають відбуватися 3 повагою до гідності, взагалі не мають містити насильства. Ст. 7 наголошує, що будь-який акт, рішення, що призведуть до невиправданої загибелі тварини, є злочином проти життя. Юридичний статус тварин, їх права мають бути визнані законом5. Проте Декларація про права тварин не була схвалена на міжнародному рівні.

У 2003 р. за участю низки міжнародних організацій була розроблена Всесвітня декларація добробуту тварин (Universal Declaration on Animal Welfare - UDAW) ${ }^{6}$. Проект Декларації містить принципи у сфері захисту тварин від жорстокого поводження, запобігання, просування стандартів добробуту тварин (зокрема, домашніх). У разі iii підписання вона стане основним констатуючим документом, що визнає існування обов'язків людини під час поводження з тваринами, зобов'язує включення в національне законодавство держав-членів ООН актів про добробут тварин ${ }^{7}$. Так, тваринам, що знаходяться в умовах неволі мають бути надані права «п’яти свобод»: на воду, корм, необхідних для підтримки здоров'я та життєвих сил; на комфортні умови утримання; відсутність відчуття білю від ран і хвороб; не відчувати страх і страждання; на природну поведінку, достатньо місця для проживання, сприятливі умови, спілкування з іншими тваринами такого ж виду. Власники зобов’язані нести відповідальність за турботу, забезпечення належних умов утримання протягом всього життя тварини.

Проект сприяє просуванню порядку реєстрації, стерилізації домашніх тварин їх власниками. Торгівля тваринами має бути предметом суворого контролю. Знищення власницьких тварин негуманними методами забороняється, в тому числі отруєння, відстріл, побиття, задушення ${ }^{8}$.

\footnotetext{
4 Всесвітня Декларація прав тварин від 23 вересня 1977 p. URL: https://uk.wikipedia.org/ wiki/Всесвітня_декларація_прав_тварин.

5 там же

6 Universal Declaration on Animal Welfare (UDAW) URL: https://en.wikipedia.org/wiki/ Universal_Declaration_on_Animal_Welfare.

7 Зубченко Н.I. Міжнародно-правове співробітництво держав у сфері забезпечення добробуту тварин та їх захисту від жорстокого поводження : монографія / під наук. ред. Т.Р. Короткого. Одеса : Фенікс, 2016. С. 90.

8 Universal Declaration on Animal Welfare. URL: http://www.animalsmatter.org/downloads/ UDAW_Text_2005.pdf
} 
Всесвітня декларація добробуту тварин не містить імперативів, відсутні санкційні норми. У разі їі прийняття вона стане джерелом норм «м'якого права», що має важливе значення в сучасному механізмі міжнародно-правового регулювання як регламентація захисту прав людини ${ }^{9}$.

Європейське законодавство не містить положень щодо захисту прав безпритульних тварин і правил поводження з ними. Система забезпечення добробуту вихованців, їх захисту від жорстокого поводження базується на унікальному міжнародному договорі - Європейській конвенції про захист домашніх тварин 1987 p. ${ }^{10}$ (далі - Конвенція).

Метою Конвенції є сприяння добробуту власницьких тварин, забезпечення мінімальних стандартів їх лікування, захисту. Визначаються основні принципи благополуччя тварин, принципи їх утримання, розведення, дресирування; встановлюються вікові обмеження у придбанні вихованців, використанні тварин у комерційних цілях, рекламі, розважальних заходах; регламентується правовий режим створення, функціонування притулків для тварин; передбачаються допустимі випадки проведення хірургічних операцій тощо.

Конвенція про захист домашніх тварин містить правила поводження з безпритульними тваринами. Так, безпритульною твариною визнається домашня тварина, яка або не має притулку, або знаходиться за межами оселі свого власника чи хазяїна, не перебуває під контролем чи безпосереднім наглядом будь-якого власника чи господаря. До безпритульних належать: (1) тварини, що ніколи не були домашніми; (2) загублені тварини; (3) покинуті домашні тварини.

За даними Stray Animal Control Practices (Europe), WSPA and RSPCA International (2006-2007 pp.), 70\% безпритульних собак є спадково безпритульними, $15 \%$ - загубленими, $5 \%$ - покинутими ${ }^{11}$. Згідно зі ст. 3 Конвенції, ніхто не має права залишати тварину на вулиці12.

\footnotetext{
9 Зубченко Н.I. Міжнародно-правове співробітництво держав у сфері забезпечення добробуту тварин та їх захисту від жорстокого поводження : монографія / під наук. ред. Т.Р. Короткого. Одеса : Фенікс, 2016. С. 92.

10 Universal Declaration on Animal Welfare. URL: http://www.animalsmatter.org/downloads/ UDAW_Text_2005.pdf

11 Stray Animal Control Practices (Europe): A report into the strategies for controlling stray dog and cat populations adopted in thirty-one countries. URL: http://www.stray-afp.org/nl/wp-content/ uploads/2012/09/WSPA-RSPCA-International-stray-control-practices-in-Europe-2006-2007 (дата звернення: 24.02.2020).

12 European Convention for the Protection of Pet Animals CETS № 125. URL: https://rm.coe. int/CoERMPublicCommonSearchServices/DisplayDCTMContent?documentId=090000168007a6 $7 \mathrm{~d}$ (date of treatment: 20.02.2020).
} 
Зменшення кількості безпритульних тварин можливо у безболісний спосіб, який не викликає страждань, пригнічення. Відлов таких тварин повинен проводитись зі заподіянням мінімальних фізичних і психічних страждань.

Країни, що приєдналися до Конвенції, зобов'язуються забезпечити постійну ідентифікацію тварин за допомогою спеціальних методів, що спричиняють незначні біль, страждання чи пригнічення. Наприклад, за допомогою татуювання, введення реєстру номерів тварин разом із прізвищами та адресами їхніх власників. Із метою попередження збільшення популяції безпритульних тварин має проводитись стерилізація. Країни зобов'язуються створити систему заохочення осіб, що знаходять безпритульних тварин i повідомляють про це компетентні органи. Відступ від принципів допускається лише в разі здійснення національних програм боротьби з хворобами.

Важливою складовою частиною системи поводження із безпритульними тваринами $є$ інформація й освіта населення. Обов'язком держави визнається сприяння проведенню освітніх та інформаційних програм стосовно положень Конвенції.

Відповідно до ст. 2 Конвенції держави-учасниці у процесі прийняття національного законодавства у сфері захисту домашніх тварин мають змогу вийти за їі рамки, розширити інструментарій захисту. Україна ратифікувала Європейську конвенцію про захист домашніх тварин 18 вересня 2013 р., імплементація в національне законодавство триває поступово.

\section{2. Правова регламентація прав тварин \\ в національному законодавстві}

Ступінь відповідності правового регулювання поводження з безпритульними тваринами в Україні європейським стандартам потребує детального дослідження. Варто зазначити, що на момент ратифікації Європейської конвенції про захист домашніх тварин в Україні у 2006 р. вже був прийнятий спеціальний нормативно-правовий акт - Закон України «Про захист тварин від жорстокого поводження» ${ }^{13}$ (далі - Закон), спрямований на захист від страждань і загибелі тварин унаслідок жорстокого поводження з ними, захист їхніх природних прав, укріплення моральності й гуманності суспільства.

13 Про захист тварин від жорстокого поводження : Закон України від 04.08.2017 p. № 3447-IV. URL: https://zakon.rada.gov.ua/laws/show/3447-15 (дата звернення: 22.02.2020). 
До того ж законодавчими актами, що регулюють суспільні відносини у сфері поводження 3 тваринами, є Цивільний кодекс України ${ }^{14}$, Закон України «Про тваринний світ» ${ }^{15}$, Закон України «Про ідентифікацію та реєстрацію тварин» ${ }^{16}$ і Правила тримання собак, котів і хижих тварин у населених пунктах Української РСР ${ }^{17}$.

Відповідно до ст. 180 Цивільного кодексу України, тварини є особливим об'єктом цивільних прав. На них поширюється правовий режим речі, крім випадків, встановлених законом. Отже, вітчизняне законодавство зараховує тварин до об’єктів, хоча й з особливим статусом. Близько дванадцяти країн ЄС зараховують тварин до суб'єктів права ${ }^{18}$. Зокрема, у Цивільному кодексі Німеччини з 1990 р. зазначено: тварини не речі (Division 2, section 90 a) ${ }^{19}$. У Цивільному кодексі Франції тварини розглядаються як живі істоти, наділені чутливістю (Article 515-14, Code civil) ${ }^{20}$.

Закон визнає безпритульними тваринами «домашніх тварин, що залишилися без догляду людини або утворили напіввільні угруповання, здатних розмножуватися поза контролем людини» ${ }^{21}$. Законодавчо відсутня норма, що передбачала б відповідальність власника за залишення домашньої тварини.

Очевидно, що основою взаємодії людини та тварини є усвідомлення тварини як живої істоти, здатної відчувати, а тому заслуговує особливого ставлення, поваги. Крім того, принципи поводження

14 Цивільний кодекс України: Закон України від 16.01.2003 p. № 435-IV. URL: https://zakon.rada.gov.ua/laws/show/435-15 (дата звернення: 22.02.2020).

15 Про тваринний світ: Закон України від 04.10.2018 p. № 2894-III. URL: https://zakon.rada.gov.ua/laws/show/2894-14 (дата звернення: 28.11.2019).

16 Про ідентифікацію та реєстрацію тварин : Закон України від 09.12.2015 p. № 1445-VI. URL: https://zakon.rada.gov.ua/laws/show/1445-17 (дата звернення: 22.02.2020).

17 Правила тримання собак, котів і хижих тварин у населених пунктах Української РСР : Затв. Наказом Мін-ва житлово-комунального господарства УРСР, Мін-ва сільського господарства УРСР та МОЗ УРСР від 17.06.1980 p. URL: https://zakon.rada.gov.ua/laws/show/ n0001303-80 (дата звернення: 22.02.2020)

18 Auffret van der Kemp T., «To which animals does animal welfare apply in law and why?» Hild S. \& Schweitzer L. (Eds), Animal Welfare: From Science to Law. 2019. Pp. 47-56. URL: http://www.fondation-droit-animal.org/proceedings-aw/to-which-animals-does-animal-welfareapply-in-law-and-why/

19 Bürgerliches Gesetzbuch. URL: https://www.gesetze-im-internet.de/bgb/ (дата звернення: 22.02.2020).

20 Code civil. URL: https://www.legifrance.gouv.fr/affichCodeArticle.do;jsessionid=CF1496A 94127C285BA12EFF8676CF3E8.tpdila23v_3?idArticle=LEGIARTI000030250342\&cidTexte=L EGITEXT000006070721\&categorieLien=id\&dateTexte (дата звернення: 22.02.2020).

21 Про захист тварин від жорстокого поводження: Закон України від 04.08.2017 р. № 3447-IV. URL: https://zakon.rada.gov.ua/laws/show/3447-15 (дата звернення: 22.02.2020). 
3 тваринами, вказані в Законі, тяжіють до антропоцентризму, що в контексті ратифікації Конвенції неприпустимо, оскільки ії концепція передбачає природоцентричні тенденції ${ }^{22}$.

Конвенція висуває однакові вимоги як до розведення чи утримання домашніх тварин для комерційних цілей, так і для тих, хто утримує притулок для тварин. Українське законодавство містить загальні вимоги проведення організації робіт з утримання домашніх тварин у притулках. Так, на виконання ст. 15 Закону у 2010 р. Державним комітетом ветеринарної медицини України було затверджене Положення про притулок для тварин ${ }^{23}$. Цей підзаконний нормативно-правовий акт здійснює загальне регулювання порядку створення притулків, визначає правила утримання тварин у притулку, проведення ветеринарних операцій (наприклад, кастрація, евтаназія у разі виявлення у тварини особливо небезпечних інфекційних хвороб, тяжких травм, несумісних iз життям, невиліковних хвороб чи інших підстав для іï проведення). Положення не передбачає стандартів утримання безпритульних тварин у притулках, ветеринарного догляду.

Законом визначено два методи регулювання чисельності тварин: (1) біостерилізація; (2) евтаназія (умертвіння). Дозволено умертвіння, новонародженого приплоду тварин у процесі регулювання чисельності диких тварин і тварин, що не утримуються людиною, але перебувають в умовах, повністю або частково створених діяльністю людини. Вбивство здорових тварин у світі не визнається евтаназією. Оскільки остання передбачає припинення страждань, спричинених невиліковними хворобами чи сильними тілесними ушкодженнями тощо. Таким чином евтаназія, що дозволена в Україні, суперечить принципам гуманного ставлення до тварин, їх захисту від жорстокого поводження ${ }^{24}$. Евтаназія здорових тварин негативно впливає на формування поваги, виховання гуманного ставлення до тварин.

Питання регулювання чисельності безпритульних тварин регулюється шляхом застосування біостерилізації або інших біологічно обгрунтованих методів, а в разі неможливості їх застосування -

\footnotetext{
22 Зубченко Н.I. Міжнародно-правове співробітництво держав у сфері забезпечення добробуту тварин та їх захисту від жорстокого поводження : монографія / під наук. ред. Т.Р. Короткого. Одеса : Фенікс, 2016. с. 14.

23 Про затвердження положення про притулок для тварин : Наказ Державного комітету ветеринарної медицини України від 15.10.2010 p. № 439. URL: https://zakon.rada.gov.ua/laws/ show/z1016-10 (дата звернення: 22.02.2020).

24 Безпритульні тварини: вбити неможливо прихистити? Екологія. Право. Людина. URL: http://epl.org.ua/eco-analytics/bezprytulni-tvaryny-vbyty-nemozhlyvo-pryhystyty/. (дата звернення: 17.02.2020).
} 
евтаназії. Зазначені методи не мають розглядати як елементи системи регуляції популяції безпритульних тварин.

В Україні системно не вирішується проблема щодо побудови механізму попередження появи на вулицях безпритульних тварин, зменшення їх кількості шляхом реєстрації, стерилізації, адопції, освітньо-просвітницьких заходів, створення умов підвищеної відповідальності власників домашніх тварин щодо їх утримання. Так, реєстрація домашніх тварин, передбачена Правилами тримання собак, котів і хижих тварин у населених пунктах Української РСР 1980 р..$^{25}$, не відповідає вимогам сьогодення. До того ж реєстрація тварин на національному рівні не ведеться, відсутні умови, порядок здійснення реєстрації, їх реєстраційна база. Така ситуація сприяє збільшенню кількості безпритульних через неможливість встановлення власників загублених чи покинутих тварин.

Відсутність законодавчої регламентації порядку розведення, приплоду собак і котів спричинює зростання популяції безпритульних тварин.

В Україні недостатня кількість притулків для тварин, що пояснюється відсутністю зацікавленості органів місцевого самоврядування у фінансуванні такої діяльності. Ситуація потребує правового вирішення питання фінансування та виділення земельних ділянок для створення притулків. Цікавою та результативною видається пропозиція надавати змогу займатись розведенням тварин виключно спеціалізованим розплідникам чи особам, які мають відповідну ліцензію. За таких умов адопція тварин із притулків стане більш популярною та доступнішою порівняно з купівлею породистих тварин ${ }^{26}$.

Запровадження на державному рівні освітніх і просвітницьких програм, спрямованих на формування гуманного, відповідального ставлення до домашніх тварин, сприятиме скороченню популяції безпритульних тварин. Залучення власників тварин і дітей до просвітництва дасть змогу суттєво вплинути на виправлення ситуації в майбутньому. Різноманітні Програми поводження $з$ домашніми тваринами

\footnotetext{
25 Правила тримання собак, котів і хижих тварин у населених пунктах Української РСР : Затв. Наказом Мін-ва житлово-комунального господарства УРСР, Мін-ва сільського господарства УРСР та МО3 УРСР від 17.06.1980 p. URL: https://zakon.rada.gov.ua/laws/show/ n0001303-80 (дата звернення: 22.02.2020).

26 Безпритульні тварини: вбити неможливо прихистити? Екологія. Право. Людина. URL: http://epl.org.ua/eco-analytics/bezprytulni-tvaryny-vbyty-nemozhlyvo-pryhystyty/. (дата звернення: 17.02.2020).
} 
зарекомендували себе у багатьох країнах світу як дієвий інструмент виховання в зазначеній сфері ${ }^{27}$.

Одним із кроків адаптування національного законодавства до права СС у питанні відповідальності за жорстоке поводження з тваринами стало прийняття Закону України «Про внесення змін до деяких законодавчих актів України щодо запровадження гуманного ставлення до тварин» 2017 p. ${ }^{28}$. Цим нормативним актом запроваджено істотне посилення відповідальності за жорстоке поводження 3 тваринами. Так, згідно з ч. 1 ст. 89 Кодексу України про адміністративні правопорушення (далі - КУПАП) знущання над тваринами, завдання побоїв або вчинення інших насильницьких дій, що завдали тварині фізичного болю, страждань і не спричинили тілесних ушкоджень, каліцтва чи загибелі, залишення тварин напризволяще, у тому числі порушення правил утримання тварин, тягнуть за собою накладення штрафу від двохсот до п'ятисот неоподатковуваних мінімумів доходів громадян 3 конфіскацією тварини, якщо перебування тварини у власника становить загрозу для іiі життя або здоров'я ${ }^{29}$. Попередня редакція зазначеної статті передбачала за жорстоке поводження з тваринами, їх мордування або вчинення інших дій, що призвели до їх мучення, каліцтва чи загибелі, накладення штрафу від дев'яти до двадцяти одного неоподатковуваного мінімуму доходів громадян.

Відповідно до ст. 299 Кримінально кодексу України (далі КК України) умисне мучення тварин, їх калічення, нацьковування одної на одну або вбивство караються арештом, обмеженням, позбавленням волі. За вказаний злочин передбачається відповідальність у вигляді арешту (до 3 років), обмеження (від 3 до 5 років) та позбавлення волі (від 3 до 8 років). Найвища міра покарання передбачена за вчинення злочину з особливою жорстокістю. До внесення змін максимальним покаранням було позбавлення волі строком до 2 років $^{30}$.

Викладені положення свідчать про формально значне збільшення міри покарання за жорстоке поводження 3 тваринами. Разом із тим

27 FAO. 2014. Dog population management. Report of the FAO/WSPA/IZSAM expert meeting - Banna, Italy, 14-19 March 2011. Animal Production and Health Report. No. 6. Rome. URL: http://www.fao.org/3/a-i4081e.pdf (дата звернення: 23.02.2020).

28 Про внесення змін до деяких законодавчих актів України щодо запровадження гуманного ставлення до тварин: Закон України від 22.06.2017 p. № 2120-VIII. URL: https://zakon.rada.gov.ua/laws/show/2120-19 (дата звернення: 14.12.2019).

29 Кодекс України про адміністративні правопорушення: станом на 01.01.2020р./ Верховна Рада УРСР. Київ : Парлам. вид-во, 2020. 1122 с.

30 Кримінальний кодекс України: станом на 01.01.2020 p. / Верховна Рада України. Київ : Парлам. вид-во, 2020. 131 с. 
більшість громадських зоозахисників та адвокатів, що спеціалізуються в цій сфері, вважають зазначені норми малоефективними ${ }^{31}$. Санкції аналогічних норм у країнах ЄС відрізняються більш суворим покаранням. Наприклад, у Франції лише за неналежний догляд за домашньою твариною власника можуть зобов'язати сплатити штраф у розмірі від 15000 до 30000 євро або позбавити волі до 2 років. В Австрії власнику за покинуту тварину загрожує рік за гратами. Більшість діянь, що підпадають під кваліфікацію за ст. 299 КК України, залишаються латентними через байдужість суспільства або небажання правоохоронних органів розслідувати такі злочини.

Рівень правопорушень, що вчиняються у сфері захисту тварин, залишається стабільно високим. Наприклад, на грудень 2016 р. в Україні було обліковано 113 правопорушень, кваліфікованих за ст. 299 КК України, на грудень 2017 р. їх зафіксовано 105. Аналіз судової практики свідчить про застосування судами порівняно м'якої міри покарання за вказані правопорушення ${ }^{32}$.

Впровадження в національне законодавство європейських стандартів у сфері поводження з тваринами здійснюється доволі повільно. Так, «Проект Закону України № 7220 «Про внесення змін до деяких законодавчих актів України (щодо запровадження обліку домашніх та безпритульних тварин)», зареєстрований ще 20 жовтні 2017 р. (далі - Проект № 7220) $)^{33}$, врегульовував умови життя безпритульних тварин. Серед нововведень передбачалося: (1) регулювання чисельності тварин винятково гуманними методами - шляхом стерилізації та реєстрації (а не евтаназії); (2) створення відкритої електронної бази даних обліку домашніх і безпритульних тварин; (3) заборона проведення хірургічних операцій, не пов'язаних $з$ наданням ветеринарної допомоги або біостерилізації; (4) заборона умертвіння новонародженого приплоду, вагітних самок, умертвіння з метою регулювання чисельності тварин тощо; (5) заборона умертвіння домашніх і безпритульних тварин для вживання в їжу, а також використання їхніх хутра та шкіри, окрім тварин сільськогосподарського призначення.

31 Воліна Т. Побиття тварини є тяжким злочином, відповідальність за який може не настати. Юридична практика 14.09-20.09.2019. URL: https://zib.com.ua/ua/139231-pobittya_ tvarini_e_tyazhkim_zlochinom_vidpovidalnist_za_yaki.html (дата звернення: 24.02.2020).

32 Славко А.С. Міжнародні стандарти захисту тварин та їх імплементація до українського законодавства / А.С. Славко, В.І. Ходико. Журнал східноєвропейського права. 2018. № 51. C. 138-145. URL: http://nbuv.gov.ua/UJRN/jousepr_2018_51_20.

33 Проект Закону про внесення змін до деяких законодавчих актів України (щодо запровадження обліку домашніх та безпритульних тварин) № 7220 від 20.10.2017 p. URL: http://w1.c1.rada.gov.ua/pls/zweb2/webproc4_1?pf3511=62763 (дата звернення: 24.02.2020). 
Поза увагою залишилася проблема перебування безпритульних тварин у так званих «місцях тимчасового утримання», «мініпритулках». 3 огляду на самоусунення органів місцевого самоврядування у питанні поводження з безпритульними тваринами, ними опікуються волонтери, громадські організації тощо. Доопрацьований законопроект зміг би змінити ситуацію в Україні із безпритульними тваринами, проте 29 серпня 2019 р. він був відкликаний.

18 травня 2018 р. за № 6598 відбулася реєстрація проекту Закону України «Про внесення змін до деяких законодавчих актів України (щодо імплементації положень деяких міжнародних угод та директив СС у сфері охорони тваринного та рослинного світу)» ${ }^{34}$, окремі положення якого спрямовувалися на регулювання чисельності безпритульних тварин методом біостерилізації з подальшою вакцинацією та кліпсуванням (евтаназія виключалася). Передбачалося внесення змін до ст.ст. 22-24 Закону України «Про захист тварин від жорстокого поводження» в питанні поводження із безпритульними тваринами. Проект також не був прийнятий.

У грудні 2019 р. до Верховної Ради подано проект Закону України № 2351 «Про внесення змін до деяких законодавчих актів України (щодо імплементації положень деяких міжнародних угод та директив ЄС у сфері охорони тваринного та рослинного світу)» ${ }^{35}$. Зазначений законопроект у питанні поводження із безпритульними тваринами є фактично ідентичним законопроекту № 6598. Запропоновано зміни до ст. 89 КУпАП, що дадуть змогу накладати штрафи за порушення ст.ст. 18, 20-23, 25, 26 Закону України «Про захист тварин від жорстокого поводження». У лютому 2020 р. проект Закону України № 2351 був прийнятий у першому читанні.

\section{ВИСНОВКИ}

В Україні відсутня цілісна система правового регулювання відносин людини та домашньої тварини, запровадження якої сприяло б посиленню відповідальності власників тварин, попередженню появі безпритульних, підвищенню культури поводження з ними. Зменшення

\footnotetext{
34 Проект Закону України «Про внесення змін до деяких законодавчих актів України (щодо імплементації положень деяких міжнародних угод та директив ЄС у сфері охорони тваринного та рослинного світу)» від 21.06.2017 p. № 6598. URL: http://w1.c1.rada.gov.ua/pls/ zweb2/webproc34?id=\&pf3511=62062\&pf35401=426953 (дата звернення: 24.02.2020).

35 Проект Закону «Про внесення змін до деяких законодавчих актів України (щодо імплементації положень деяких міжнародних угод та директив ЄС у сфері охорони тваринного та рослинного світу)» 30.10.2019 p. № 2351. URL: http://w1.c1.rada.gov.ua/pls/zweb2/webproc34? $\mathrm{id}=\& \mathrm{pf3511}=67235 \& \mathrm{pf35401}=507245$ (дата звернення: 24.02.2020).
} 
популяції безпритульних тварин гуманними методами видається можливим шляхом впливу на першопричину цієї проблеми. Для вирішення зазначеного на законодавчому рівні мають бути чітко визначені правила поводження з домашніми тваринами та передбачена відповідальність за їх порушення.

Переконані, що правовий механізм врегулювання кількості безпритульних тварин має передбачати елемент обов’язкової реєстрації тварин, що дозволить встановити кількість домашніх і безпритульних тварин. Наступним елементом має бути обов'язкова стерилізація тварин, як власницьких, якщо не планується їх розмноження, так і безпритульних, що дасть змогу попередити неконтрольовану популяцію. Наприклад, у Німеччині для попередження збільшення кількості безпритульних тварин, а також для заохочення адопції тварин із притулків передбачена обов'язкова стерилізація для домашніх тварин ${ }^{36}$. Дісвим методом у подоланні збільшення кількості безпритульних тварин визнано ліцензування розведення тварин. 3 одного боку, біостерилізація дає змогу уникати небажаного приплоду, з іншого боку, ліцензування примушує тих, хто має намір займатися розведенням, відповідально ставитись до своєї діяльності.

Наступним важливим елементом механізму є збільшення кількості притулків за активної фінансової й організаційної участі органів місцевого самоврядування з відповідними умовами та ветеринарним обслуговуванням. Важливим напрямом у сфері поводження з тваринами є пропагування їх адопції. У світі напрацьована значна кількість заходів щодо стимулювання усиновлення тварин, встановлення над ними опіки.

\section{АНОТАЦІЯ}

Визнано, що основою взаємодії людини та тварин є усвідомлення останніх як живих істот, здатних відчувати, таких, що заслуговують особливого ставлення, поваги. Пошук дієвого й адаптованого до реалій сьогодення правового регулювання у сфері поводження з безпритульними тваринами в Україні є метою цього дослідження. Гуманність підходів вирішення зазначеної проблеми залежить від різних аспектів, у тому числі від рівня економічного розвитку країни. Стандарти гуманного ставлення до тварин є однією з європейських цінностей, сприйняття та втілення яких розглядаються як необхідні з огляду на євроінтеграційні процеси в Україні.

\footnotetext{
36 Безпритульні тварини: вбити неможливо прихистити? Екологія. Право. Людина. URL: http://epl.org.ua/eco-analytics/bezprytulni-tvaryny-vbyty-nemozhlyvo-pryhystyty/. (дата звернення: 17.02.2020).
} 
Законодавство України не передбачає жодного зобов'язання, покладеного на органи місцевого самоврядування й органи виконавчої влади стосовно створення притулків для тварин, виділення коштів із бюджету на їх утримання. Регулювання чисельності безпритульних тварин має здійснюватися шляхом застосування біологічно обгрунтованих методів, але фактично застосовується метод евтаназії.

3 метою зменшення популяції безпритульних тварин гуманними методами на законодавчому рівні мають бути закріплені взаємоузгоджені правила поводження 3 домашніми тваринами та передбачена відповідальність за їх порушення. Сформована необхідність нормативного врегулювання питання обов'язкової реєстрації тварин, процесу розведення, продажу.

\section{ЛІТЕРАТУРА}

1. Безпритульні тварини: вбити неможливо прихистити? Екологія. Право. Людина. URL: http://epl.org.ua/eco-analytics/bezprytulni-tvarynyvbyty-nemozhlyvo-pryhystyty/ (дата звернення: 17.02.2020).

2. Воліна Т. Побиття тварини є тяжким злочином, відповідальність за який може не настати. Юридична практика. 14.09-20.09.2019 p. URL: https://zib.com.ua/ua/139231-pobittya_tvarini_e_tyazhkim_zlochinom_ vidpovidalnist_za_yaki.html (дата звернення: 24.02.-2020).

3. Всесвітня Декларація прав тварин від 23 вересня 1977 p. URL: https://uk.wikipedia.org/wiki/Всесвітня_декларація_прав_тварин.

4. Гомілко О. Вітальна єдність людини та тварини: свідомість як квалія. URL: http://ekmair.ukma.edu.ua/handle/123456789/13358

5. Зубченко Н.І. Міжнародно-правове співробітництво держав у сфері забезпечення добробуту тварин та їх захисту від жорстокого поводження : монографія / під наук. ред. Т.Р. Короткого. Одеса : Фенікс, 2016. 284 с.

6. Кодекс України про адміністративні правопорушення : станом на 01.01.2020 р. / Верховна Рада УРСР. Київ: Парлам. вид-во, 2020. 1122 с.

7. Кримінальний кодекс України: станом на 01.01.2020 р. / Верховна Рада України. Київ : Парлам. вид-во, 2020.131 с.

8. Правила тримання собак, котів і хижих тварин у населених пунктах Української РСР : Затв. Наказом М-ва житлово-комунального господарства УРСР, М-ва сільського господарства УРСР та МОЗ УРСР від 17.06.1980 p. URL: https://zakon.rada.gov.ua/laws/show/n0001303-80 (дата звернення: 22.02.2020).

9. Про внесення змін до деяких законодавчих актів України щодо запровадження гуманного ставлення до тварин: Закон України від 22.06.2017 p. № 2120-VIII. URL: https://zakon.rada.gov.ua/laws/show/ 2120-19 (дата звернення: 14.12.2019). 
10. Про затвердження положення про притулок для тварин: Наказ Державного комітету ветеринарної медицини України від 15.10 .2010 р. № 439. URL: https://zakon.rada.gov.ua/laws/show/z1016-10 (дата звернення: 22.02.2020).

11. Про захист тварин від жорстокого поводження : Закон України від 04.08.2017 р. № 3447-IV. URL: https://zakon.rada.gov.ua/laws/show/ 3447-15 (дата звернення: 22.02.2020).

12. Про ідентифікацію та реєстрацію тварин: Закон України від 09.12.2015p. № 1445-VI. URL: https://zakon.rada.gov.ua/laws/show/144517 (дата звернення: 22.02.2020).

13. Про тваринний світ: Закон України від 04.10.2018 p. № 2894-III. URL: https://zakon.rada.gov.ua/laws/show/2894-14 (дата звернення: 28.11.2019).

14. Проект Закону «Про внесення змін до деяких законодавчих актів України (щодо імплементації положень деяких міжнародних угод та директив ЄС у сфері охорони тваринного та рослинного світу)» 30.10.2019 p. № 2351. URL: http://w1.c1.rada.gov.ua/pls/zweb2/webproc34?i $\mathrm{d}=\& \mathrm{pf3511}=67235 \& \mathrm{pf35401}=507245$ (дата звернення: 24.02.2020).

15. Проект Закону про внесення змін до деяких законодавчих актів України (щодо запровадження обліку домашніх та безпритульних тварин) № 7220 від 20.10 .2017 p. URL: http://w1.c1.rada.gov.ua/pls/ zweb2/webproc4_1?pf3511=62763 (дата звернення: 24.02.2020).

16. Проект Закону України «Про внесення змін до деяких законодавчих актів України (щодо імплементації положень деяких міжнародних угод та директив ЄС у сфері охорони тваринного та рослинного світу)» від 21.06.2017 p № 6598. URL: http://w1.c1.rada.gov.ua/pls/zweb2/webproc34?

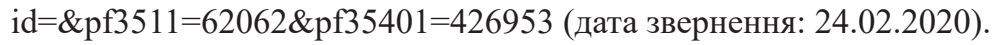

17. Славко А.С. Міжнародні стандарти захисту тварин та їх імплементація до українського законодавства / А.С. Славко, В.І. Ходико. Журнал східноєвропейського права. 2018. № 51. С. 138-145. URL: http://nbuv.gov.ua/UJRN/jousepr_2018_51_20.

18. Цивільний кодекс України: Закон України від 16.01.2003 p. № 435-IV. URL: https://zakon.rada.gov.ua/laws/show/435-15 (дата звернення: 22.02.2020).

19. FAO. 2014. Dog population management. Report of the FAO/WSPA/ IZSAM expert meeting - Banna, Italy, 14-19 March 2011. Animal Production and Health Report. No. 6. Rome. URL: http://www.fao.org/3/a-i4081e.pdf (дата звернення: 23.02.2020).

20. Code civil. URL: https://www.legifrance.gouv.fr/affichCodeArticle.do;j sessionid $=$ CF1496A94127C285BA12EFF8676CF3E8.tpdila23v_3?idArticle= 
LEGIARTI000030250342\&cidTexte=LEGITEXT000006070721\&categorieL ien=id\&dateTexte (дата звернення: 22.02.2020).

21. Auffret van der Kemp T., «To which animals does animal welfare apply in law and why?» [PDF file]. Hild S. \& Schweitzer L. (Eds), Animal Welfare: From Science to Law. 2019. Pp. 47-56. URL: http://www.fondation-droit-animal.org/proceedings-aw/to-which-animalsdoes-animal-welfare-apply-in-law-and-why/

22. Bürgerliches Gesetzbuch. URL: https://www.gesetze-im-internet.de/ bgb/ (дата звернення: 22.02.2020).

23. European Convention for the Protection of Pet Animals CETS № 125. URL: https://rm.coe.int/CoERMPublicCommonSearchServices/DisplayDCT MContent?documentId=090000168007a67d (date of treatment: 20. 02.2020).

24. Mice Change Their Appearance as a Result of Frequent Exposure to Humans. URL: https://www.technology.org/2018/03/16/mice-change-theirappearance-as-a-result-of-frequent-exposure-to-humans/ (date of treatment: 16.02.2020).

25. Stray Animal Control Practices (Europe): A report into the strategies for controlling stray dog and cat populations adopted in thirty-one countries. URL: http://www.stray-afp.org/nl/wp-content/uploads/2012/09/WSPA-RSPCAInternational-stray-control-practices-in-Europe-2006-2007 (date of treatment: 24.02.2020).

26. Universal Declaration on Animal Welfare. URL: http://www.animalsmatter.org/downloads/UDAW_Text_2005.pdf

27. Universal Declaration on Animal Welfare (UDAW). URL: https://en.wikipedia.org/wiki/Universal_Declaration_on_Animal_Welfare

\section{Information about authors:}

Churilova T. N.,

Ph.D.,

Associate Professor of the International, European Law and Civil Law Department

Sumy State University

2, Rimskyi-Korsakov str., Sumy, Ukraine

Strelnyk V. V.,

Ph.D.,

Associate Professor of the Private and Social Law Department

Sumy National Agrarian University 160, H. Kondratiieva str., Sumy, Ukraine

DOI https://doi.org/10.30525/978-9934-588-43-3/2.27 